\title{
"Disciplinando a vida, a começar pela escola"": a militarização das escolas públicas do estado da Bahia
}

\author{
"Discipline in life, starting with the schools": \\ the militarization of the public schools in the state of Bahia \\ "Disciplinando la vida: comenzando por la escuela ": \\ la militarización de las escuelas públicas en el estado de Bahía \\ ELIANA POVOAS PEREIRA ESTRELA BRITO \\ MARIZE PINHO REZENDE
}

\begin{abstract}
Resumo: Este texto objetiva compreender o acelerado crescimento dos processos de militarização das escolas públicas no estado da Bahia. Utiliza conceitos retirados do pensamento foucaultiano e de outros autores contemporâneos que teorizam as relações de poder nas sociedades atuais. Argumenta que a entrada da polícia militar nos cotidianos escolares faz circular um novo tipo de controle que se organiza em torno da gestão da vida e se exerce pelo engendramento de técnicas disciplinares aos dispositivos de segurança.
\end{abstract}

Palavras-chave: militarização; escolas públicas; dispositivos de segurança.

Abstract: This text aims at understanding the rapid growth of the projects of the militarization of public schools in the state of Bahia. It resorts to concepts taken from Michel Foucault's works as well as from other contemporary authors that theorize the relations of power in today's society. It argues that the participation of the police in the school's daily activities creates a new type of control that is built around the management of life is applied by the development of disciplinary techniques and safety devices.

Keywords: militarization; public schools; safety devices.

Resumen: Este texto tiene como objetivo comprender el crecimiento acelerado de los procesos de militarización de las escuelas públicas en el estado de Bahía. Utiliza conceptos tomados del pensamiento foucaultiano y de otros autores contemporáneos que teorizan las relaciones de poder en las sociedades actuales. Argumenta que la entrada de la policía militar en la escuela cotidiana hace circular un nuevo tipo de control que se organiza alrededor de la gestión de la vida y se ejerce mediante el engendrar de técnicas disciplinarias a los dispositivos de seguridad.

Palabras-clave: militarización; escuelas públicas; dispositivos de seguridad.

1 Título do projeto-piloto apresentado pela Secretaria Municipal de Educação do município de Santa Cruz Cabrália - BA para firmar o Termo de Acordo de Cooperação Técnica, em 18/09/2018. 


\section{INTRODUÇÃO}

Estou muito otimista quanto a esta parceria valiosa com o Comando Geral da PM, que escolheu Sobradinho para implantar o sistema de ensino dos colégios da corporação, que são considerados os melhores da Bahia, com altos índices de aprovação no Enem e muito bem-conceituados. A metodologia disciplinar será aliada ao nosso projeto pedagógico, sem interferência no conteúdo ministrado pelos professores. (Site da Prefeitura Municipal de Sobradinho, publicado em 1/08/2018).

Momento de celebração para o município de Santa Cruz Cabrália. Foi assinado nesta terça-feira (18), o termo de acordo de cooperação técnica para implementação do Sistema de Ensino dos Colégios da Polícia Militar da Bahia na Escola Municipal Victurino da Purificação Figueiredo. (Site Prefeitura Municipal de Santa Cruz Cabrália, publicado em 18/09/2018).

Hoje a educação do município de Vereda dá um importante passo para a melhoria do sistema de ensino, principalmente no que diz respeito à disciplina dentro das escolas [...] (Site da Prefeitura Municipal de Vereda, publicado em 21/01/2019). "A implantação do novo modelo visa a somar esforços, para que, juntos, nós e a Polícia Militar possamos contribuir, de maneira substancial, para o melhor desempenho escolar de nossos jovens. A ideia é que o aspecto disciplinar e a parte pedagógica, agindo em parceria com as famílias, criem uma base sólida através da qual grandes cidadãos e cidadãs serão formados" (Site da Prefeitura de Serrinha, publicado em 17/04/2019).

Optamos por abrir este artigo com fragmentos de notícias extraídos de portais das prefeituras municipais do estado da Bahia (BA), na medida em que anunciam, logo de saída, a força crescente dos movimentos que militarizam as escolas públicas baianas, capitaneados pelas prefeituras municipais com vistas a firmar o Acordo de Cooperação Técnica com a Polícia Militar da Bahia.

No Brasil, os processos de militarização da educação avançaram nos últimos cinco $a_{n o s}^{2}$ e colocaram em circulação um conjunto discursivo que correlaciona a indisciplina à violência, dando visibilidade ao risco social e, por efeito, à necessidade de segurança nos cotidianos escolares. De acordo com esses discursos, uma escola disciplinada pela "filosofia e metodologia" dos militares significa o "sonho" almejado na contemporaneidade pela sociedade em geral e pelas comunidades escolares de forma específica, pois, "agora, é outro mundo,

2 Seguimos aqui o levantamento realizado por Castro (2016, p.14), quando afirma que foi no início do ano de 2014 que uma ação do Governo de Goiás ofereceu "Novos contornos para pensar o panorama da educação básica por instituições militares. Sancionada no mês de julho do ano anterior, a lei 18.108 estabeleceu a criação de treze novas unidades de ensino do modelo CPMG (Colégios da Polícia Militar de Goiás). Entretanto, a 'criação' não envolvia a construção física de treze novos colégios, mas o repasse de instituições de ensino já existentes da gestão exclusiva pela Secretaria de Educação às mãos da Polícia Militar. A mudança de administração dessas escolas ocorreu em finais de 2013, de modo que o ano letivo sob o novo modelo começou em janeiro do ano seguinte em dez das treze unidades criadas. As outras três foram inauguradas ao longo de 2014". 
os próprios professores perguntam como nós conseguimos tornar esse sonho em realidade. Antes, eram os alunos que mandavam na escola" (Capitão Francisco dos Santos Silva, em entrevista à BBC Brasil, 2014).

Aprendemos com Foucault que as sociedades disciplinares, constituídas ao longo dos sécs. XVII e XVIII, colocaram em funcionamento um conjunto de dispositivos de poder que, ao bloquearem a prática do suplício, enquanto técnica corretiva e disciplinar, deram lugar a um tipo de poder que se ocupou em trabalhar o corpo de forma detalhada e minuciosa. O controle minucioso do corpo, objetivando imprimir-lhe docilidade-utilidade, tem nas instituições de sequestro (fábrica, presídio, hospital, escola etc.) espaços/tempos privilegiados de ação. "É assim que no exército aparecem sistemas de graus que vão, sem interrupção, do general chefe até o ínfimo soldado, como também os sistemas de inspeção, revistas, paradas, desfiles etc., que permitem que cada indivíduo seja observado permanentemente" (FOUCAULT, 2010, p.106).

Nas trilhas das sociedades disciplinares, analisadas por Foucault, Deleuze (1992, p, 220), anuncia que as "Sociedades disciplinares é o que já não éramos mais, o que deixávamos de ser". Trata-se de uma crise generalizada que engloba todos os meios de confinamento (prisão, hospital, fábrica, escola, família), iniciados nos séculos XVIII e XIX, cujo apogeu se deu no século XX. Para Deleuze, a gestão dessa crise dar-se-á por meio de constantes reformas nos diferentes setores. Reformar a reforma será o trabalho dos governantes em busca do controle e da estabilidade dessas instituições que, até então, haviam respondido com efetividade aos caprichos do capital e sua crescente demanda pela produção de corpos dóceis e úteis, necessários ao avanço do capitalismo.

Deleuze (Idem, p. 216) afirma que "Estamos entrando nas sociedades de controle, que funcionam não mais por confinamento, mas por controle contínuo e comunicação instantânea". Já não se trata de um tipo de poder que, a um só tempo, individua e massifica, ou ainda, "Molda a individualidade de cada membro do corpo" (Idem, p. 220). Nas sociedades de controle, a economia do poder assume outra racionalidade. Agora, o controle, ao contrário das sociedades disciplinares, não requer mais espaços fechados para se exercitar. Dessa forma, se nas sociedades disciplinares o poder operava por confinamento, concentrando pessoas, distribuindo-as no espaço, ordenando-as no tempo, hoje, os exercícios de poder dão-se a céu aberto. Ou seja, já não há mais a necessidade de enclausurar para governar.

$\mathrm{O}$ autor argumenta que "Tentam nos fazer acreditar numa reforma da escola, quando se trata de uma liquidação" (Idem, p. 225). Ao defender que os controles são uma modelação, "moldagem auto-deformante" (Ibidem), aposta que a educação se afastará cada vez mais da necessidade de ser realizada em espaços 
fechados em favor "Das formas de controle contínuo, avaliação contínua, e a ação da formação permanente sobre a escola, o abandono correspondente de qualquer pesquisa na Universidade, a introdução da 'empresa' em todos os níveis de escolaridade" (DELEUZE, 1992, p. 225).

Baumam (2001), ao analisar as mudanças ocorridas nas sociedades contemporâneas, também anuncia o fim do tipo de configuração de poder presente nas disciplinas. Para ele, no mundo líquido moderno, as relações de poder encontram-se reconfiguradas, na medida em que não há mais a necessidade de enclausuramento e de vigilância constantes. Há uma espécie de decadência do modelo panóptico utilizado nas sociedades disciplinares, analisadas por Foucault. Nesse sentido, o autor vai dizer que:

O fim do Panóptico é o arauto do fim da era do engajamento mútuo: entre supervisores e supervisados, capital e trabalho, líderes e seguidores, exércitos em guerra. As principais técnicas do poder são agora a fuga, a astúcia, o desvio e a evitação, a efetiva rejeição de qualquer confinamento territorial, com os complicados corolários de construção e manutenção da ordem, e com a responsabilidade pelas consequências de tudo, bem como com a necessidade de arcar com os custos (p. 18).

$\mathrm{Na}$ fase "líquida" da modernidade, o controle e/ou uma vigilância contínua seriam dispendiosos e não alcançariam seus objetivos, na medida em que já não se trata mais de homogeneizar comportamentos, padronizar posturas, corrigir idiossincrasias. Os princípios de ocupação do tempo e do espaço utilizados nas disciplinas - enfileirar, seriar, esquadrinhar o tempo e o espaço - cedem lugar a uma outra configuração ocupacional, uma espécie de "labirinto para ratos" (BAUMAN, 2009, p. 667), rompendo com as possibilidades de fixar o espaço e delimitar o tempo. Há uma desregulamentação social.

Sobre a mobilidade dos fluidos, 'Eles 'fluem', 'escorrem', 'esvaem-se', 'respingam', ‘transbordam', 'vazam', 'inundam', 'borrifam', 'pingam', são ‘filtrados', 'destilados"' (BAUMAN, 2001, p. 8); ao mesmo tempo em que nos dão uma sensação de "leveza", produzem uma reação de incerteza, que, conforme o autor, é a única certeza que temos. Com o declínio da certeza, proteção e segurança, o medo passa a fazer parte da condição humana da chamada "modernidade líquida" (Idem). Frente à ausência de esperança de que haja controle e domínio sobre o mundo social e natural, as incertezas, perigos e ameaças passam a rondar a vida. Por efeito, conforme nos adverte o autor, apegamo-nos a toda e qualquer possibilidade de vir a ter segurança. Não à toa, o comércio de seguros é um dos setores que mais se ramifica e prospera na atualidade (segurança pessoal, segurança pública, seguro desemprego, seguro acidente, seguro incêndio, seguro viagem, dentre tantos outros). 
Beck (2006), em Incertezas fabricadas (entrevista concedida ao Instituto Humanitas Unisinos - IHU - On-Line), analisa as sociedades contemporâneas enquanto "Sociedade de risco" e argumenta que não se trata de quantificar o quanto as sociedades vivem ameaçadas por diversos riscos. Para ele, a questão central fica por conta da "Qualidade do controle ou - para ser mais preciso - a sabida impossibilidade de controle das consequências das decisões civilizacionais que faz a diferença histórica". O autor argumenta que a expectativa institucionalizada de controle, ou mesmo, as ideias-chave de certeza e de racionalidade estão em colapso. Para nomear essa desestabilização, Beck vai utilizar a expressão "incertezas fabricadas". E explica:

Não são as mudanças climáticas, os desastres ecológicos, ameaças de terrorismo internacional, o mal da vaca louca etc. que criam a originalidade da sociedade de risco, mas a crescente percepção de que vivemos em um mundo interconectado que está se descontrolando (BECK, 2006, p.7).

Para Beck, no "paradigma da sociedade de risco" o que está em jogo não é liberação das pessoas às sujeições tradicionais (as desigualdades econômicas, por exemplo), na medida em que é o próprio processo de modernização que se torna tema e problema, ou seja, trata-se de um processo reflexivo. Por ocasião da entrevista antes referenciada, quando questionado sobre o significado do poder nas sociedades de risco, Beck responde que, nessa nova configuração social, o problema central das relações de poder se configura pela disputa em torno da ideia de que alguém é responsável e a ideia de que ninguém é responsável. E acrescenta:

Políticos dizem que não estão no comando, que eles no máximo regulam a estrutura para o mercado. Especialistas científicos dizem que meramente criam oportunidades tecnológicas: eles não decidem como elas serão implementadas. Gente de negócios diz que está simplesmente respondendo a uma demanda dos consumidores. A sociedade tornou-se um laboratório sem nenhum responsável pelos resultados do experimento (BECK, 2006, p. 8).

Diante da anunciada "irresponsabilidade organizada", as incertezas emergem e desorientam os "Mapas cognitivos interaccionais e societais em que até agora temos confiado. Os mapas que nos são familiares deixaram de ser confiáveis" (SANTOS, 2002, p. 41), trazendo novos desafios para as instituições de controle (escola, fábrica, hospício, asilo etc.), sendo que, "A cultura do medo vem do fato paradoxal de que as instituições feitas para controlar produzem incontrolabilidade" (BECK, 2006, p.7). 
Nesse quadro de discussão, em que pesem as significativas diferenças conceituais presentes em cada uma das perspectivas de compreensão apresentadas, o fato é que esses estudos apontam para a necessidade de pensarmos a maquinaria escolar para além do funcionamento das engrenagens que, pelo menos, em parte, vinham orientando nossas análises. Em poucas palavras, por um lado, já não se trata de pensar as sociedades atuais mantendo intocada a concepção de sociedades disciplinares estudadas por Foucault. Por outro, como compreender a emergência e acelerado crescimento de militarização da educação pública em um momento histórico marcado pela liquidez social (BAUMAN, 2001, 2009), pelo risco social (BECK, 2006) e pelo controle social anunciado por Deleuze (1992)? A que tipo de racionalidade política remetem os processos de militarização da educação pública brasileira?

Essas e tantas outras questões relativas à militarização das escolas públicas brasileiras constituem-se em pautas prioritárias na agenda de pesquisadores/ pesquisadoras brasileiros/brasileiras assumindo maior centralidade com a inusitada publicação do Decreto 9.465/2019, quando o Presidente Bolsonaro (2019-2022) inaugurou suas práticas de governo (dois dias após ter tomado posse), reestruturando o Ministério da Educação (MEC) e atribuindo à Secretaria de Educação Básica, por meio de uma subsecretaria inventada para:

\begin{abstract}
Promover, fomentar, acompanhar e avaliar, por meio de parcerias, a adoção por adesão do modelo de escolas cívico-militares nos sistemas de ensino municipais, estaduais e distrital tendo como base a gestão administrativa, educacional e didático-pedagógica adotada por colégios militares do Exército, Polícias e Bombeiros Militares. "promover, progressivamente, a adesão ao modelo" a criação de um novo modelo de escola: "Escolas Cívico-Militares (BRASIL, 2019, Art. 11, Inciso VI).
\end{abstract}

Em recente entrevista ${ }^{3}$ coletiva concedida aos órgãos de comunicação pelo atual Ministro da Educação, Abraham Weintraub, e pelo secretário de Educação Básica, Jânio Macedo, foi apresentada à imprensa uma espécie de planejamento estratégico, intitulado: "Compromisso Nacional pela Educação Básica" contendo metas para a Educação Básica até o ano de 2022. De acordo com o documento, estão previstos a implantação e fomento de "27 Escolas Cívico Militares (1 por estado), totalizando 108 escolas até 2023, atendendo, aproximadamente, 108 mil alunos." A meta proposta é a de "Aproximar e igualar, progressivamente, o Ideb das Escolas Públicas do Ensino Básico ao Ideb dos Colégios Militares” (MEC/

\footnotetext{
3 Entrevista concedida no dia 11 de julho de 2019, com transmissão online pelo Facebooke e outras mídias digitais. Na ocasião foi anunciado que o documento apresentado como uma espécie de "carta-compromisso" para a Educação Básica, iniciativa do MEC, contou com a colaboração do Conselho Nacional de Secretários de Educação (Consed) e União Nacional dos Dirigentes Municipais de Educação (Undime).
} 
CONSED/UNDIME, 2019). DOCUMENTO....). Ainda, conforme o referido documento, atualmente, existem 203 ECM no Brasil em 23 Estados e no Distrito Federal, totalizando 192 mil alunos. A intenção do governo é a de fortalecer, anualmente, 28 ECM (uma por estado), totalizando 112 escolas até 2023, atendendo, aproximadamente, 112 mil alunos (MEC/ CONSED/UNDIME, 2019).

Inscrito nessa pauta de problematização e considerando-se a recente (e acelerada) instauração de processos de militarização das escolas públicas municipais do estado da Bahia, o presente artigo objetiva contribuir para o debate acerca das questões que envolvem esses processos, na medida em que compreendemos que se trata da emergência de uma nova problemática para a educação brasileira e, enquanto tal, requeira que esforços de pesquisa sejam feitos em prol do necessário aprofundamento desse tema.

O corpus deste trabalho constitui-se por um conjunto de discursos presentes em recortes de noticiários divulgados pelas mídias (digital e impressa) do estado da Bahia, bem como por documentos oficiais (projetos, regulamentos, regimentos, termos de acordos, dentre outros) utilizados para efetivar os acordos de cooperação técnica entre as prefeituras e a polícia militar, objetivando a implantação do chamado "Sistema de Ensino dos Colégios da Polícia Militar da Bahia". Para além disso, foram feitas algumas inserções de campo em uma das escolas militarizadas, localizada no município de Santa Cruz Cabrália, região sul baiana.

Para tanto, estruturamos o texto da seguinte maneira: inicialmente discorremos sobre o processo de militarização das escolas públicas no estado da Bahia, com o objetivo de identificar suas singularidades frente ao quadro mais geral da militarização das escolas públicas brasileiras. Logo a seguir, operacionalizamos alguns conceitos foucaultianos, em especial as noções de dispositivo de segurança, normalização e risco, buscando compreender as estratégias políticas e as técnicas de poder que se exercem nessa nova configuração escolar. Por fim, tecemos algumas considerações que, embora não sejam conclusivas, abrem o leque a novas e outras problematizações preocupadas com essa temática.

\section{MOVIMENTOS QUE MILITARIZAM AS ESCOLAS PÚBLICAS}

\section{BAIANAS}

No âmbito do estado da Bahia, pode-se dizer que a declaração de apoio do governador do estado, Rui Costa, em 18/03/2018, em prol da efetivação de um convênio entre a Diretoria de Ensino da Polícia Militar da Bahia (PM-BA) e a União dos Municípios da Bahia (UPB), tenha servido de estopim para que as 
prefeituras, por meio de suas secretarias de educação, dessem início à construção de projetos voltados à "transferência da tecnologia educacional" " dos Colégios da Polícia Militar (CPM) para escolas do interior do estado.

A ampla divulgação na mídia de que o governo baiano havia manifestado a intenção de assinar acordo para implantação da "metodologia e filosofia" dos colégios militares em municípios baianos gerou críticas imediatas, por parte de entidades representativas dos profissionais da educação - Associação Nacional pela Formação dos Professores da Educação (Anfope); Sindicato dos Trabalhadores em Educação do Estado da Bahia (APLB), dentre outros) - e do próprio Ministério Público Federal, que abriu instauração de inquérito civil público vinculado à Procuradoria Regional dos Direitos do Cidadão (PRDC), para "Conhecer e acompanhar as condições da aplicação de metodologia dos colégios militares em escolas municipais, em decorrência de convênio firmado pela PM/ BA e a União dos Municípios da Bahia (UPB)". (MPF/PRDC/BA, 2018).

Diante da pressão social, o governo do estado, por meio do da Secretaria Estadual da Educação (SEC) declarou ter havido "incompreensão" sobre o convênio firmado entre a PM e a União dos Municípios da Bahia, "sem a participação da SEC", com o objetivo "De ofertar a tecnologia educacional da rede CPM a escolas de municípios baianos". No entanto, o então superintendente de política para Educação Básica da Secretaria Estadual da Educação (SEC), Sr. Ney Campello argumentou que "disciplina nada tem a ver com autoritarismo". E acrescentou:

O que eu não tenho é o preconceito com aprendermos com a experiência. Do mesmo jeito que temos experiência de escolas quilombolas, escolas indígenas e escolas comunitárias, o CPM também é uma experiência. Precisamos desmilitarizar o preconceito, acabar com esse patrulhamento das experiências (A TARDE, s/d) publicado em 19/03/2018).

O equívoco político-conceitual das comparações tecidas pelo então responsável pela pasta da Educação Básica na Secretaria Estadual da Educação na Bahia evidencia a tentativa de silenciamento do longo processo histórico de

4

O projeto de militarização das escolas baianas vem sendo discutido desde 2016. É importante destacar que o Deputado Estadual Pastor Sargento Isidório (PROS) apresentou um Projeto de Lei, de número 21.798/2016, que autoriza a implantação, por meio de convênios do governo do Estado e dos municípios, da adoção do modelo de funcionamento e disciplina dos colégios militares. Disponível em www.al.ba.gov.br/ docs/Proposicoes2016/PL_21_798_2016_1.rtf. No entanto, “a ideia desse projeto de lei não é transformar as escolas públicas em colégio militar, mas utilizar a sua filosofia e metodologia. Como afirma o autor do Projeto de Lei, em letras maiúsculas: "AUMENTAR O NÚMERO DE ESCOLAS ESTADUAIS E MUNICIPAIS NO FORMATO GENÉRICO / SIMILAR DOS CPMs É UMA RESPOSTA PRÁTICA E ACESSÍVEL DO PODER PÚBLICO, pois o molde militar de ensino é uma excelente alternativa aos dias difíceis que passa o Ensino Brasileiro". Disponível em: http://www.blogdopaulonunes.com/v4/?p=27411. Acesso em 01 jun. de 2019. 
lutas dos povos indígenas e quilombolas em prol da conquista de seus direitos (educação escolar quilombola e indígena), com significativa participação dos povos indígenas e quilombolas do estado da Bahia para inscrever a militarização escolar nessa discursividade. De acordo com a fala do secretário da SEC, políticas educacionais voltadas à inclusão das diferenças e políticas destinadas à homogeneização das diferenças podem ser pensadas em um nível de entendimento comum: 'experiências' educacionais.

As manifestações contrárias vindas a público, questionando a arbitrariedade (e reacionarismo) dessa nova configuração política proposta à escola pública não foram suficientes para barrar o, processo. Embora o governo do estado não tenha ficado a frente desse processo, o fato é que, em pouco mais de um ano, o estado da Bahia assistiu (e continua a assistir) a um crescimento vertiginoso no quantitativo de municípios ${ }^{5}$ que fizeram adesão ao termo de acordo entre escola e Polícia Militar.

Considerado pelas prefeituras como um "grande avanço na educação", um "marco na história da educação", cada um dos municípios baianos, ao assinar o Termo de Cooperação Técnica com a Polícia Militar do Estado da Bahia, festejou o acontecimento e divulgou em seus portais farto material sobre o assunto: fotos da comunidade escolar comemorando a iniciativa e discursos políticos e militares carregados de promessas de felicidades para as comunidades escolares:

É um grande projeto do Comando Geral da PM Bahia. O município vai entrar com a parte pedagógica e a Polícia Militar com a parte disciplinar e cívica, será muito bom para os nossos alunos. Temos certeza que este projeto só tende a crescer porque os frutos são visíveis. Agradecemos por essa iniciativa junto ao município de Filadélfia (PREFEITURA MUNICIPAL DE FILADÉLFIA S/d) Publicado em: 29/05/2019)

O Termo de Acordo de Cooperação Técnica (POLÍCIA MILITAR DA BAHIA, s/d. 2019), comum a todas as escolas que fazem adesão ao "sistema CPM", estabelece o modelo de gestão escolar: "A gestão da escola se dará de forma harmônica entre o diretor escolar e o diretor militar" (s.p.), sendo que “O primeiro fica responsável pela administração e pelo processo pedagógico e o segundo pela disciplina escolar, de forma a permitir a eficiência na implementação da proposta pedagógica" (idem).

5 De acordo com o Portal Bahia Notícias, em 14 de fevereiro de 2019, 36 municípios já haviam assinado o acordo e se encontravam em fase de implantação do chamado "Sistema CPM" (Colégio da Polícia Militar) em escolas da rede municipal de educação 
Sobre as obrigações dos partícipes, dentre outros encargos, cabe à Polícia Militar da Bahia: "Indicar militares da reserva remunerada ou reformados para as funções de Diretor Militar, Coordenador Disciplinar e Tutores que atuarão na escola" (idem), bem como, "Capacitar através de cursos específicos os/ as diretores/diretoras escolares e coordenadores/as podendo se estender aos professores/as e funcionários/as da escola" (idem). Ao município, dentre outras responsabilidades, cabe "Disponibilizar a instituição de ensino com (sic) instalações físicas compatíveis com o modelo de ensino da Rede de Colégio da Polícia Militar (CPM); remunerar os policiais militares indicados para exercer as suas respectivas funções" (idem).

Percebe-se, por efeito, que o 'sistema CPM COM' impõe um novo regime de organização e financiamento para a educação das escolas que o integram. Importa sublinhar que a polícia militar disponibiliza profissionais reformados para atuarem nas escolas. Esses militares, independente da formação acadêmica, são remunerados pelas prefeituras parceiras como se fossem professores contratados para o exercício de 40 horas semanais. Além disso, o militar que atua como 'diretor militar' recebe um salário mais elevado.

Baseado no princípio do controle e da disciplina militar, a escola passa a ter uma gestão compartilhada (polícia-pedagógica) em que o padrão comportamental exigido pela disciplina militar serve como balizador para que os processos de ensino-aprendizagem ocorram. Como disse o comandante Brandão, "aqui seremos colaboradores, e essa nova gestão vai aliar a pedagogia à disciplina, o que ajudará a formar futuros cidadãos” (PREFEITURA MUNICIPAL DE BARREIRAS, s/d).

Conforme regulamento disciplinar de uma das escolas integrantes ao 'sistema CPM', "A competência para aplicar sanção disciplinar é inerente ao cargo e não ao grau hierárquico”, sendo competentes para aplicá-las:

I - Professor regente, supervisor de conduta: advertência e repreensão; IICoordenador pedagógico: advertência e repreensão; III - Direção (diretor ou vice-diretor) da escola: advertência, repreensão, suspensão de sala de aula e transferência educativa com anuência do conselho tutelar. (Idem).

O novo regime discursivo que rege o trabalho dos/das profissionais da educação, em especial das equipes diretivas, deixa de vincular-se aos paradigmas que até então respaldavam as práticas de gestão escolar (gestão democrática e participativa) e passam a ser regulados pela racionalidade militar (hierarquização, disciplina e metodologia). Ancorados em pesquisas que revelam que os índices de violência urbana, violência escolar e indisciplina nas escolas, além de se constituírem em risco social, interferem diretamente nas aprendizagens, 
os discursos que circulam a favor da militarização das escolas correlacionam disciplina com sucesso escolar e tomam os Colégios da Polícia Militar da Bahia como instituições exemplares de bons índices de desempenho nas avaliações ${ }^{6}$ (ENEM e IDEB), quando comparados com as demais instituições escolares do estado da Bahia, o que leva a PM afirmar que "os colégios militares na Bahia são um sucesso ${ }^{7}$ ".

Sem considerar as singularidades presentes nos colégios militares e sem exigir contrapartida das prefeituras em relação a equipamentos, infraestrutura e melhores condições de trabalho docente, os discursos das prefeituras centramse em promessas que se restringem à prática administrativa e docente dos profissionais da educação. "Hoje, a diretora dedica 90\% do seu tempo resolvendo problemas administrativos e assuntos ligados à violência e drogas. Agora, poderá se concentrar no desenvolvimento do processo de aprendizagem dos alunos" (PREFEITURA MUNICIPAL DE BARREIRAS/BA, s/d).

Opera-se nessa discursividade um deslocamento referente à centralidade que historicamente vem sendo atribuída aos professores/às professoras frente ao insucesso e fracasso escolar. A figura do/da professor/professora, que historicamente tem sido responsabilizada pelo insucesso e, por efeito, tem sido alvo de inúmeras e variadas políticas de capacitação, atualização, aperfeiçoamento, dentre outras, adquire, agora, novos contornos. Não é que o professor/a professora não saibam ensinar. O fato é que ele/ela não conseguem ensinar porque a indisciplina dos/das escolares não permite: “Os professores se queixam da indisciplina dos alunos, até de ameaças, da falta de atenção, saídas de sala de aula, circulação entre uma sala e outra". "É a oportunidade de os professores terem o tempo pedagógico disponível para eles" (BAHIA NOTÍCIAS. s/d Publicado em 14 de fevereiro de 2018).

\footnotetext{
6 De acordo com os dados revelados pelo IDEB (2015), o nível de ensino nas escolas militares supera as demais unidades escolares de todo o país. O Índice de Desenvolvimento da Educação Brasileira (IDEB), de 2015, apontou 5,5 pontos como média obtida pela Educação Básica, enquanto os colégios militares alcançaram notas acima de 6 e 7 .

7 De acordo com as manifestações da Polícia Militar em reportagem da BBC News Brasil, intitulada: Continência, 'inspeção de cabelo’ e tutoria de PMs: a rotina em uma escola com regras e disciplina militares. Disponível em: https://www.bbc.com/portuguese/geral-45491630. Acesso em abril de 2019.
} 


\section{DISPOSITIVOS DE SEGURANÇA, RISCO E NORMALIZAÇÃO}

Temos observado no noticiário desta região (sul da Bahia), registros de ações
próprias, comuns ao tráfico de drogas como sequestros de alunos em escolas,
aliciamento de alunos em horário de aulas para práticas de delitos diversos -
espancamentos, roubo a mão armada, realização do comércio de drogas. Esses
fatos tornam-se tão comuns diante do não-exercício de controle mais intenso
no espaço escolar, cuja medida preventiva ou repressora é incluir no cotidiano
uma rotina com caráter disciplinador, a fim de evitar/inibir, combater e superar
esse cenário prejudicial à atividade escolar (PREFEITURA MUNICIPAL DE
SANTA CRUZ DE CABRÁLIA/Secretaria Municipal de Educação, 2018, s/p).

O discurso que justifica a presença da polícia militar nas escolas baianas inscreve-se nas paisagens sociais, econômicas e políticas que caracterizam as sociedades atuais onde o declínio da autoridade, da proteção e da segurança, instituiu o medo como condição do homem contemporâneo. Constata-se que as escolas vivenciam, com profundidade, as implicações dessas transformações sociais e, por efeito, estratégias de segurança passam a engendrar os dispositivos políticopedagógicos voltados à "Promoção da aquisição de conhecimentos necessários à conquista da cidadania” (SANTA CRUZ DE CABRÁLIA/SEMED). Em poucas palavras, a polícia disciplinar promete, pelo controle dos riscos, a realização do sonho de um projeto de escola entendido "Como lugar central em que as aprendizagens sociais e intelectuais se dão de modo sistematizado" (Idem).

Nesse sentido, concordamos com os estudos críticos quando apontam que, com o desmantelamento do Estado Providência, com a derrocada do regime fordista e sob a égide da globalização, os dispositivos de governo já não se exerçam aos moldes das disciplinas. Parece-nos evidente que hoje exista uma nova economia das relações de poder e que o controle social exija relações mais complexas do que aquelas exercidas pelo panóptico.

Estas questões, quando refletidas no âmbito da educação escolarizada (no contexto nacional e internacional), remetem a uma crise de legitimidade da escola (DAYRELL, 2007; KRAWCZYK, 2011) que independente da "Tese utilizada para caracterizar o momento vivido atualmente pela instituição escolar e pela educação, o que se destaca é a distância entre o que a sociedade espera da escola e o que a escola tem sido capaz de oferecer" (LEÃO; DAYRELL; REIS, p. 255). Essas questões apontam, conforme Dayrell (2007), para a constatação de que existe "uma nova condição juvenil" no Brasil, resultado das mutações nos processos mais amplos de socialização.

Essas questões, quando pensadas na perspectiva da militarização das escolas públicas, levam-nos a defender o argumento de que a entrada da polícia militar nos cotidianos escolares faz circular, a partir de uma nova economia de 
poder, um novo tipo de controle social. Esse novo tipo de poder se organiza em torno da gestão da vida e se exerce pelo engendramento de técnicas disciplinares aos dispositivos de segurança. Dito de outra maneira, o modelo "escola militarizada" ou, ainda, utilizando a expressão do atual governo, "escola cívicomilitar", inscreve-se no solo discursivo das sociedades de risco e tem na segurança social sua principal justificativa e eficiência política.

No curso ministrado a partir de 1978, Segurança, território, população, Foucault, ao analisar a emergência da população nas práticas de governo, explicou que a entrada do biopoder (o exercício de poder sobre a vida) não elimina a disciplina, pois governar a população não quer dizer simplesmente "Administrar a massa coletiva dos fenómenos ou administrá-los simplesmente no plano dos seus resultados globais; administrar a população quer dizer administrá-la igualmente em profundidade, administrá-la com sutileza e administrá-la em detalhe" (FOUCAULT, 2008, p.142).

Embora a disciplina, em função dos riscos, tenha-se utilizado de mecanismos de segurança, "Os mecanismos de segurança também são antiquíssimos" (Idem, p.10); é a partir da entrada da população nas práticas de governo que o poder sobre a vida ("fazer viver" ou, em algumas situações, "deixar morrer"), apoiado, especialmente, nos conhecimentos da estatística, que a "percepção dos problemas específicos da população e graças ao isolamento desse nível de realidade que se chama economia, que o problema do governo pode enfim ser pensado, refletido e calculado fora do marco jurídico da soberania" (Idem, p.138).

Correlata a essas questões, a noção de risco passa a ser ressignificada. Para os cálculos do governo, a partir de então, torna-se mais econômico tratar o risco social a partir da identificação de situações de risco (espaços, comunidades, grupos populacionais) do que encarcerar indivíduos identificados como risco social. Como nos mostrou Foucault (2008, p. 80):

Esse cálculo dos riscos mostra logo que eles não são os mesmos para todos os indivíduos, em todas as idades, em todas as condições, em todos os lugares e meios. Assim, há riscos diferenciais que revelam, de certo modo, zonas de mais alto risco e zonas, ao contrário, de risco menos elevado, mais baixo, de certa forma. Em outras palavras, pode-se identificar assim o que é perigoso.

O cálculo dos riscos explica o critério utilizado pelas prefeituras municipais para a escolha das escolas que fariam o acordo de cooperação técnica com a polícia militar da Bahia. De acordo com o projeto-piloto desenvolvido pela Secretaria de Educação do município de Santa Cruz Cabrália: "Consideramos ainda a localização da escola como instituição localizada em bairro com entorno com 
predominância periférica. Entendemos esse cenário como propício ao perigo e as ameaças rondam as vias de acesso esburacadas, mal iluminadas e potencializamse na portaria escolar". Na sequência, acompanhando a compreensão da polícia militar, o projeto-piloto, transcreve a compreensão de um militar sobre a periferia urbana da região onde se localiza a escola: "Bairro periférico é o mais propício à instalação das bases do crime. Além disso, entende-se, nesse local, que qualquer ação policial pode ter sido realizada por quem não se envolve, não é mão de obra, e o cidadão de bem fica refém e condenado e sentenciado a morte" (MAJOR ARACLETO SILVA, 25/04/2018). ( (PREFEITURA MUNICIPAL DE SANTA CRUZ DE CABRÁLIA/Secretaria Municipal de Educação, 2018, s/p).

Identificada como comunidade de risco, um conjunto de dispositivos são colocados em funcionamento na escola sob a égide da garantia da segurança e da normalização dos espaços/sujeitos escolares. Não se trata mais de uma normação normativa, mas sim, no sentido estrito, de urna normalização (FOUCAULT, 2008, p. 82). Já não se trata tão somente de um processo de normalização focado no indivíduo e, sim, na comunidade escolar como um todo. O sujeito indisciplinado representa um risco não apenas para si, mas, antes, para que as pessoas da comunidade escolar possam se manter vivas, é preciso exterminar todos os perigos. Não à toa, o acordo de cooperação técnica exige que a escola construa um minucioso código disciplinar como forma de sancionar a indisciplina, mas também de gerir a vida dos sujeitos perigosos/indisciplinados e, sobretudo, evitar a virtualidade desses comportamentos:

Estabelecer a disciplina como eixo consiste no trabalho preventivo, dispersando os motivos e locais de concentração das transgressões, isto é, "a fim de evitar que” ocorra algo, antevendo-o. [...] Será adotado o regime militarizado com sanções por reciprocidade, de punição graduada conforme o teor da ocorrência (SANTA CRUZ DE CABRÁLIA/Secretaria Municipal de Educação, 2018).

Por efeito, a disciplina vai entrar na ordem do discurso pedagógico como princípio educativo a ser perseguido pela escola em nome da preservação da vida. Assim, pela regulação das condutas estudantis, a liberdade passa a ser vigiada para evitar desvios comportamentais, sendo que todo comportamento indesejável deve sofrer sanções, incluindo, dentre elas, a exclusão da escola. "A disciplina funciona como mecanismo que aponta um horizonte a ser seguido, orientando-o (o estudante) ao comportamento adequado ao espaço e às circunstâncias sociais (SANTA CRUZ DE CABRÁLIA/Secretaria Municipal de Educação, 2018).

Nesse sentido, é interessante notar que nova configuração da gestão escolar há uma economia do Estado ao priorizar a segurança através do enquadramento e tratamento de áreas, comunidades, sujeitos identificados como 
risco social. Não se fala de políticas públicas de segurança social, mas, sim, de uma espécie de segurança privada/terceirizada que, no limite, se não alcançar seus objetivos, transfere a situação para que o sujeito indisciplinado passe a administrar. $\mathrm{O} / \mathrm{a}$ estudante expulso/a por indisciplina deve reconhecer-se (e ser socialmente reconhecido) como pessoa desviante e, enquanto tal, o direito à educação fica ameaçado em nome da gestão do risco e da segurança social. Torna-se evidente o crescente deslocamento das obrigações do Estado para a responsabilização individual.

A escola como instituição que produz e sofre interferências socioculturais vem sofrendo os fluxos e os refluxos provocados pelos movimentos de desregulamentação social que marcam a nossa contemporaneidade. Sabemos que a escola, na modernidade, constituiu-se em espaço privilegiado para os exercícios do poder disciplinar, tornando-se estratégica para a fabricação de corpos dóceis e uteis para o sistema capitalista, bem como a resistência a esses processos. A normalização pautada pela norma e, baseada nela, a escola classificava, ordenava, diferenciava estudantes e aprendizagens: o bom aluno, o mal aluno, o disciplinado, o indisciplinado, o normal, o anormal. Por sua vez, os dispositivos de segurança ancorados no risco e no cálculo dos perigos, não farão uso da norma enquanto medidas previamente definidas. Trata-se, agora, de fazer uma identificação das "Diferentes curvas de normalidade, e a operação de normalização vai consistir em fazer essas diferentes distribuições de normalidade funcionarem urnas em relação às outras e [em] fazer de sorte que as mais desfavoráveis sejam trazidas às que são mais favoráveis" (FOUCAULT, 2008, p.12).

O que se passa é que nesse jogo das distribuições que vão servir de norma (“a norma está em jogo no interior das normalidades diferenciais" (idem p.16) a escola, tencionada pelas prescrições políticas presentes em decretos, diretrizes, parâmetros, reformas e pareceres, agoniza frente à impossibilidade de cumprir com as metas estabelecidas. Sem questionar um conjunto de fatores tomados como verdades absolutas nos processos de escolarização, o retorno à disciplina e à norma tornam-se tábua de salvação em face das fortes tempestades enfrentadas pelas escolas nos dias de hoje. "A disciplina que se propõe contrapõe-se à indisciplina. Ela (a disciplina) é entendida como mecanismo de tornar uniforme àquilo que inicialmente era múltiplo. Segue rituais, transforma hábitos, expressa uma vigilância sobre a conduta que deve ser praticada" (SANTA CRUZ DE CABRÁLIA/Secretaria Municipal de Educação). 


\section{CONSIDERAÇÕES FINAIS}

Não é novidade alguma que o magistério público brasileiro vem sofrendo frente a um conjunto de crises que ultrapassam os ultrajantes salários e se estendem à medicalização crescente em função de doenças adquiridas no exercício da profissão. Entre o "eu não sei lidar com essa juventude desenfreada" e o "nós queremos mais liberdade, mais criatividade e novas formas de ensino" os discursos/práticas que entrecruzam os cotidianos escolares não escondem que a escola está em crise. estudantes, gestores/as, professores/as e famílias constituem uma polifonia, nos moldes da Torre de Babel.

Muito provavelmente, a crise das disciplinas tenha dificultado as relações escolares, na medida em que, agora, não basta mais classificar, hierarquizar, ordenar e distribuir no tempo e no espaço. Como vimos, a gestão dos riscos e o cálculo dos perigos, em constantes processos de mutações e impactados pela velocidade dos acontecimentos, colocaram em funcionamento dispositivos de segurança que não afetam apenas o indivíduo, mas, antes, exercem poder sobre a vida da comunidade escolar como um todo. Nesses tempos em que os perigos rondam, em especial, as comunidades de risco, a normalização e regulação da indisciplina escolar faz parte da engrenagem dessa nova economia de poder, que torna a vida, a cada dia, mais governada aos moldes da economia de mercado.

$\mathrm{Na}$ escola, os dispositivos de segurança e seus efeitos na reestruturação das tecnologias disciplinares instauraram uma nova racionalidade política que opera a partir de uma nova economia nas relações do poder governamental típica das sociedades atuais e sua desregulamentação social. Por certo, essa desregulamentação não significa menos controle e menos regulação social, mas, sim, novas modulações de atuação do poder, provavelmente, mais eficazes.

\section{REFERENNCIAS}

A TARDE.UOL. SEC reage a críticas sobre modelo de ensino militar. Disponível em https://atarde.uol.com.br/bahia/salvador/noticias/1944427-secreage-a-criticas-sobre-modelo-de-ensino-militar. Acesso em mai. de 2019.

\section{BAHIA NOTÍCIAS. SEC firma parceria com Fundação Getúlio Vargas para formação de professores na BNCC. Disponível em: https://www. bahianoticias.com.br/noticia/240871-sec-firma-parceria-com-fundacao-getulio- vargas-para-formacao-de-professores-na-bncc.html. Acesso em: maio de 2019.}



Zahar, 2001.

BAUMAN, Zygmunt. Entrevista sobre a educação. Desafios pedagógicos e modernidade líquida. Entrevista concedida a Alba Porcheddu. Cad. Pesquisa, vol.39, no.137. São Paulo, May/Aug. 2009. Disponível em: http://www.scielo.br/ scielo.php?script $=$ sci_arttext\&pid=S0100-15742009000200016. Acesso em maio de 2017.

BECK. U. Incertezas fabricadas. IHU ONLINE. São Leopoldo, 22 de maio de 2006. Disponível em: www.unisinos.br /ihu. Acesso em: fevereiro de 2019.

BBC Brasil. Goiás aposta em 'militarização' de escolas para vencer violência. Reportagem BBC Brasil em São Paulo. Disponível em https://www.bbc.com/ portuguese/noticias/2014/08/140819_salasocial_eleicoes_educacao_escola_ militarizada_rm. Acesso em mai. de 2019.

BRASIL. Decreto n. 9465, de 2 de janeiro de 2019. Disponível em http:/ / www. in.gov.br/materia/-/asset_publisher/Kujrw0TZC2Mb/content/id/57633286 Acesso em 20 jan. 2019

CASTRO, Nicholas Moreira Borges de. "Pedagógico" e “Disciplinar": O Militarismo como Prática de Governo na Educação Pública do Estado de Goiás. 2016. p.108 Dissertação (Mestrado em Antropologia Social) Universidade de Brasilia. Brasília, 2016. Disponível em http://repositorio.unb. br/handle/10482/22204?mode=full. Acesso em 30 mai. 2019.

DAYRELL, Juarez. A escola "faz" juventudes? Reflexões em torno da socialização juvenil. 2007. Revista Educação e Sociedade, Campinas, vol. 28, n. 100 Especial, p. 1105 - 1128, out. 2007. Disponível em http://www.cedes.unicamp. br. Acesso em jul. 2017.

DELEUZE, G. Post-scriptum sobre as sociedades de controle. Conversações: 1972-1990. Rio de Janeiro: Ed. 34, 1992. p. 219-226

FOUCAULT, Michel. Microfísica do poder. Rio de Janeiro: Edições Graal, 2010. 
FOUCAULT, Michel. Segurança, Território, População. Curso no Collège de France (1977-1978). Tradução de Eduardo Brandão. São Paulo: Martins Fontes, 2008.

IHU ONLINE /IHU. Incertezas fabricadas. Entrevista com Ulrich Beck. São Leopoldo, Unissinos, 22 de Maio de 2006. Disponível em: www.unisinos.br. Acesso em mai. 2019.

KRAWCZYK, Nora Rut. Pesquisa em Educação: desenvolvimento, ética e responsabilidade social. In: DIÓGENES, Elione M. N.; PRADO, Edna (Orgs.). Avaliação de políticas públicas: interface entre educação e gestão escolar. Maceió - AL, Editora da UFAL, 2011

LEÃO, Geraldo; DAYRELL, Juarez Tarcísio; REIS, Juliana Batista. Jovens olhares sobre a escola do ensino médio. Cad. Cedes, Campinas, v. 31, n. 84, p. 253-273, maio-ago. 2011 253. Disponível em http://www.cedes.unicamp.br. Acesso em jul. 2018.

MEC/CONSED/UNDIME. Compromisso Nacional pela Educação Básica. Disponível em:http://www.brasil.gov.br/noticias/educacao-e-ciencia/2019/07/ mec-firma compromisso-para-fortalecer-a-educacao-basica. Acesso em jul. 2019.

POLÍCIA MILITAR DA BAHIA. COMANDO GERAL. Termo de Acordo de Cooperação Técnica. Celebra a cooperação entre municípios e polícia militar visando à implementação do Sistema de Ensino da P3olícia Militar da Bahia. s/d. material datilografado.

PREFEITURA MUNICIPAL DE BARREIRAS. Prefeitura de Barreiras e Polícia Militar da Bahia assinam convênio para gestão compartilhada do Colégio Municipal Eurides Sant'Anna. Disponível em: https://barreiras. ba.gov.br/prefeitura-de-barreiras-e-policia-militar-da-bahia-assinam-conveniopara-gestao-compartilhada-do-colegio-municipal-eurides-santanna/. Acesso em mai. de 2019.

PREFEITURA MUNICIPAL DE FILADÉLFIA. Prefeito de Filadélfia assina convênio para implantação de Gestão Compartilhada da PM no Ensino Público Municipal. Disponível em https://www.filadelfia.ba.gov.br/ver_ noticias.php?note=295. Acesso em ago. 2019. 
PREFEITURA MUNICIPAL DE SANTA CRUZ CABRÁLIA. Prefeito assina termo de cooperação para implantação de Colégio Militar em Cabrália. Notícia publicada em: 18/setembro de 2018. Disponível em: http:/ /www.cabralia. ba.gov.br/detalhe-da-materia/info/prefeito-assina-termo-de-cooperacao-paraimplantacao-de-colegio-militar-em-cabralia/87403. Acesso em mai. 2019.

PREFEITURA MUNICIPAL DE SANTA CRUZ CABRÁLIA. Secretaria Municipal de Educação. DV (DEVÊ): Disciplinando a vida, a começar pela escola. Projeto-piloto desenvolvido em parceria entre Escola, Secretaria Municipal de Educação e Polícia Militar da Bahia. Bahia: Santa Cruz Cabrália, 2018. Material de circulação interna.

PREFEITURA MUNICIPAL DE SERRINHA. Educação em Serrinha dá passo à frente com início de gestão compartilhada com a PM no Leobino Ribeiro. Disponível em: http://www.serrinha.ba.gov.br/v2/index.php/ servicos/smn-contribuinte/item/1748-educacao-em-serrinha-da-passo-a-frentecom-inicio-de-gestao-compartilhada-com-a-pm-no-leobino-ribeiro. Acesso em mai. de 2019.

PREFEITURA MUNICIPAL DE SOBRADINHO. Prefeitura de Sobradinho e PM Bahia assinam termo para implantar unidade escolar no Município. Notícia publicada em publicado em 16 de agosto / 2018. Disponível em: http:/ / www.sobradinho.ba.gov.br/noticias. Acesso em mai. 2019.

PREFEITURA MUNICIPAL DE VEREDAS. Prefeito comemora parceria com a PM para a educação municipal. Disponível em https://vereda.ba.gov. br/wp/. Acesso em ago. 2019.

SANTOS, Boaventura de Sousa. A crítica da razão indolente: contra o desperdício da experiência. v.4. 4.ed. São Paulo: Cortez, 2002.

ELIANA POVOAS PEREIRA ESTRELA BRITO é Mestre e Doutora em educação pela Universidade Federal do rio Grande do Sul. Professora associada do Instituto de humanidades, artes e Ciências, do Campus Sosígenes Costa, da Universidade Federal do Sul da Bahia. Atua no ensino, pesquisa e extensão no campo das políticas públicas e formação de professores/as.

E-mail: eliana.povoasbrito@gmail.com

ORCID: http://orcid.org/0000-0002-4563-1354

RBPAE - v. 35, n. 3, p. 844 - 863, set./dez. 2019 • 862 
MARIZE PINHO REZENDE é Mestrando do Programa de Pós-Graduação em Ensino e Relações Étnico-Raciais - Universidade Federal do Sul da Bahia. Professora da rede pública municipal de Santa Cruz Cabrália - Bahia.

E-mail: marizerezende@hotmail.com

ORCID: http://orcid.org/0000-0001-9715-9082

Recebido em setembro de 2019

Aprovado em setembro de 2019 